\title{
PEMETAAN SIFAT FISIK DAN KIMIA TANAH PADA TEGAKAN Pinus merkusii DI HUTAN PENELITIAN DRAMAGA, BOGOR
}

\author{
Soil Physical and Chemical Properties Mapping of Pinus merkusii Stand on Dramaga Forest \\ Research, Bogor
}

Omo Rusdiana ${ }^{1}$ dan Nuri Nursjahbani²

(Diterima April 2017/Disetujui Februari 2020)

\begin{abstract}
The environment is a complex system where various factors affect on the plant community in the forest. This theory should be proven by study of the influence of environmental factors to the vegetation of forest stands. This study aimed to analyze the effect of environmental factors, particularly edaphic factors such as soil physical and chemical properties to the vegetation and to examine the effect of edaphic variations to the vegetation variation of Pinus merkusii stands on the plot of 163, Dramaga Forest Research, Bogor. The sample of soil were disturbed sample and undisturbed sample taken by systematic sampling method. There was a tendency that the greater the properties of soil the better the vegetation growth in terms of height and diameter of pine tree. However, that effect was not significant due to the great durability of $P$. merkusii against marginal soil condition. The soil properties must be supported by other factors such as shading so that the two factors are able to manage the optimal growth of pine trees and maintain the function of forest.
\end{abstract}

Keywords: Pinus merkusii, physical properties, chemical properties, land unit, Dramaga

\section{PENDAHULUAN}

Hutan merupakan masyarakat tumbuh-tumbuhan yang dikuasai pohon-pohon dan memiliki keadaan lingkungan yang berbeda dengan keadaan di luar hutan. Lingkungan merupakan suatu sistem yang kompleks dimana berbagai faktor berpengaruh timbal balik satu sama lain dengan masyarakat tumbuh-tumbuhan (Soerianegara dan Indrawan 1988).

Seberapa jauh pengaruh lingkungan terhadap tumbuh-tumbuhan dalam sebuah ekosistem hutan dan bagaimana proses-proses yang terjadi di dalamnya perlu dipahami lebih lanjut. Perlu adanya pengkajian pengaruh faktor lingkungan terhadap vegetasi di dalam ekosistem hutan sehingga kedua hal tersebut dapat dipahami lebih mendalam. Faktor lingkungan yang dimaksud meliputi iklim, geografis, edafis, dan biotik (Billings 1952; Kramer dan Kozlowski 1960; dalam Soerianegara dan Indrawan 1988).

Penelitian ini fokus terhadap pengamatan hubungan faktor tempat tumbuh yaitu edafis terhadap populasi pohon-pohon Pinus merkusii Jungh. et De Vriese yang ada di petak 163 Hutan Penelitian Dramaga, Bogor. Hasil analisis faktor edafis berupa sifat fisik dan kimia tanah kemudian akan lebih mudah dipahami dalam bentuk peta untuk melihat lokasi dimana karakteristik tanah tersebut berada. Adapun pemilihan Hutan Penelitian Dramaga

\footnotetext{
1 Dosen Departemen Silvikultur, Fakultas Kehutanan Institut Pertanian Bogor

* Penulis korespondensi: e-mail: orusdiana@yahoo.com

2 Mahasiswa Departemen Silvikultur, Fakultas Kehutanan Institut Pertanian Bogor
}

sebagai lokasi penelitian didasarkan atas kemudahan lokasi tersebut untuk dijangkau.

Perlu adanya penelitian pemetaan sifat fisik dan kimia tanah di Hutan Penelitian Dramaga (HPD), Bogor, sehingga lokasi tersebut dapat menjadi sebuah alat untuk membuktikan teori bahwa lingkungan tempat tumbuh dapat mempengaruhi vegetasi dengan melihat hubungan antara variasi sifat fisik dan kimia tanah terhadap pohonpohon $P$. merkusii di atasnya. Penelitian ini bertujuan untuk menganalisis sifat kimia (C-organik, $\mathrm{pH}$, kejenuhan alumunium, KTK) dan sifat fisik (bulk density, porositas, warna, horizon) tanah pada setiap unit contoh di tegakan pinus petak 163, HPD; memperoleh unit lahan berdasarkan pengelompokkan sifat kimia dan sifat fisik yang sama dari setiap unit contoh; dan menganalisis hubungan antara sifat kimia dan fisik tanah pada setiap unit lahan dengan vegetasi di unit lahan tersebut.

\section{METODE PENELITIAN}

\section{Waktu dan Tempat Penelitian}

Penelitian ini dilakukan mulai bulan Oktober 2015 sampai dengan Mei 2016. Penelitian dilaksanakan di Hutan Penelitian Dramaga (50 ha), dengan objek penelitian yaitu tanah dan pohon pinus di dalam tegakan petak 163, pinus berumur 41 tahun. HPD memiliki tipe iklim A, curah hujan sebesar $3.940 \mathrm{~mm} / \mathrm{tahun}$, suhu udara rata-rata $26.3^{\circ} \mathrm{C}$, dan kelembaban udara $88.28 \%$. Jenis tanah di HPD yaitu latosol, ketinggian tempat $220 \mathrm{~m}$ dpl, dan kelerengan 0-6\%. Tegakan pinus petak 163 memiliki 
jarak tanam $6 \mathrm{~m}$ x $6 \mathrm{~m}$ dan tidak ada perlakuan khusus dalam pemeliharaan pohon.

\section{Alat dan Bahan}

Alat yang digunakan dalam penelitian ini adalah bor tanah, ring sample, cawan petri, oven, timbangan analitik, plastik sampel, pita meter, haga hypsometer, kompas, penggaris, cangkul, Munsell Soil Color Chart, diagram tekstur, alat tulis, kamera digital, label, Microsoft excel, software sexI- $f$, aplikasi paint, dan tallysheet. Bahan yang digunakan dalam penelitian ini adalah sampel tanah.

\section{Prosedur Penelitian}

Metode yang digunakan adalah metode survey dengan pengambilan sampel tanah secara sistematik (systematic sampling).

\section{Pembuatan dan penandaan unit contoh di lapang}

Dibuat petak unit contoh seluas $5 \mathrm{~m}$ x $5 \mathrm{~m}$ untuk analisis warna tanah dan $10 \mathrm{~m} \times 10 \mathrm{~m}$ untuk analisis horizon tanah, pada tegakan pinus seluas $48 \mathrm{~m}$ x $38 \mathrm{~m}$. titik amatan di lapang kemudian ditandai dengan bambu berukuran $50 \mathrm{~cm}$ yang diberi nomor titik amatan secara urut.

\section{Pengukuran pohon pinus}

Diukur tinggi total, tinggi bebas cabang, diameter, dan tajuk pohon pinus di dalam tegakan. Ditentukan koordinat $(\mathrm{x}, \mathrm{y})$ pohon pinus di dalam tegakan. Data-data tersebut kemudian diolah dengan menggunakan Microsoft ecxel dan software sexl-fs.

\section{Pengambilan sampel untuk analisis warna tanah}

Diukur tebal serasah pada 63 titik amatan sebelum pengambilan sampel tanah. Warna tanah ditetapkan dengan standar warna dari Munsell Soil Color Chart. Warna tanah yang sama pada titik amatan kemudian dikelompokkan dan dibuat peta sederhana menggunakan aplikasi paint.

\section{Pengambilan sampel untuk analisis horizon tanah}

Digali 12 lubang dengan jarak antar lubang $10 \mathrm{~m} \mathrm{x}$ $10 \mathrm{~m}$ untuk analisis horizon tanah. Setiap lubang digali hingga kedalaman $60 \mathrm{~cm}$, kemudian dianalisis secara langsung jenis dan ketebalan horizon tanah. Dikelompokkan lubang amatan yang memiliki horizon
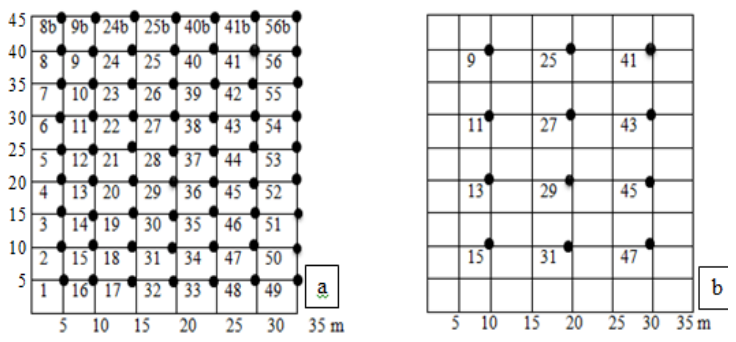

Gambar 1 Peta pengambilan sampel:(a) analisis warna tanah;(b) analisis horizon tanah sama. Titik yang memiliki tipe horizon tanah sama dihubungkan sesuai area yang berdekatan. Diamati pula drainase melalui bercak yang timbul pada penampang horizon tanah.

Pengelompokkan warna dan horizon tanah yang sama untuk mendapat unit contoh tanah

Dilakukan overlay pada kelompok titik amatan yang memiliki warna dan tipe horizon tanah yang sama. Dibuat peta baru hasil overlay tersebut. Hasil overlay berupa kelompok unit contoh tanah.

\section{Pengambilan sampel untuk analisis sifat kimia tanah}

Diambil sampel tanah terganggu pada setiap titik amatan berdasarkan kelompok unit contohnya. Diambil 3 ulangan pada titik yang berdekatan dengan titik amatan pada kelompok unit contoh yang hanya memiliki 1 titik amatan. Pengambilan sampel tanah komposit untuk keperluan analisis C-organik, $\mathrm{pH}$, kejenuhan alumunium, dan KTK.

\section{Pengambilan sampel untuk analisis bulk density dan porositas tanah}

Diambil sampel tanah utuh pada setiap unit contoh untuk analisis bulk density dan porositas tanah. Setiap unit contoh terdapat 3 ulangan dan dipilih berdasarkan ketebalan serasah rata-rata. Penetapan bulk density dan porositas tanah dihitung dengan menggunakan metode ring tanah.

\section{Pengelompokkan sifat fisik dan kimia tanah yang sama untuk mendapat unit lahan}

Sifat kimia dikategorikan berdasarkan kategori sifat kimia tanah menurut Pusat Penelitian Tanah dalam buku Hardjowigeno (2007). Kelompok unit contoh yang memiliki sifat kimia dan fisik tanah yang sama kemudian dikelompokkan. Hasil pengelompokkan berupa unit lahan.

Analisis hubungan antara sifat tanah dan vegetasi pinus pada setiap unit lahan

Unit lahan kemudian dideskripsikan. Kondisi unit lahan tersebut kemudian dihubungkan dengan kondisi pohon-pohon pinus yang masuk ke dalam setiap unit lahan.

\section{HASIL DAN PEMBAHASAN}

\section{Pengelompokan unit contoh berdasarkan warna dan horizon tanah}

Didapat 5 kelompok warna tanah dari 63 titik amatan seperti pada gambar 2. Pengelompokkan (untuk tahap selanjutnya) dipisahkan pada jalur paling kanan, karena pada jalur tersebut terdapat kondisi yang tidak sama dengan kondisi area lain di dalam tegakan pinus, yaitu adanya tumpukan sampah.

Perbedaan warna permukaan tanah dapat dipengaruhi oleh keberadaan serasah di atas tanah. 
Diukur tebal serasah pada setiap titik amatan dan dihitung rata-rata tebal serasah berdasarkan kelompok warna tanah.

\section{Horizon Tanah}

Didapat 2 tipe horizon tanah pada tegakan pinus HPD. Masing-masing tipe horizon memiliki 3 jenis horizon penyusun pada kedalaman amatan hingga $60 \mathrm{~cm}$, yaitu horizon O, A, dan B. Setiap horizon pada setiap titik amatan memiliki tekstur tanah yang sama yaitu silty clay loam atau lempung liat berdebu. Oleh karena jenis horizon penyusun dan tekstur tanah pada setiap titik amatan adalah sama, maka perbedaan tipe horizon didasarkan pada warna tanah di horizon B, yaitu dark brown untuk tipe 1 dan dark reddish brown untuk tipe 2.

Dilakukan overlay pada kelompok warna dan tipe horizon tanah yang sama. Kemudian dibuat peta baru hasil overlay tersebut. Hasil overlay berupa unit contoh yang baru, yaitu terdapat 13 kelompok unit contoh.

Dibuat peta sederhana dari 13 kelompok unit contoh. Titik amatan pada kelompok yang sama ditandai dengan warna titik yang sama pada peta.

\section{Pengelompokkan unit lahan berdasarkan sifat kimia dan fisik tanah}

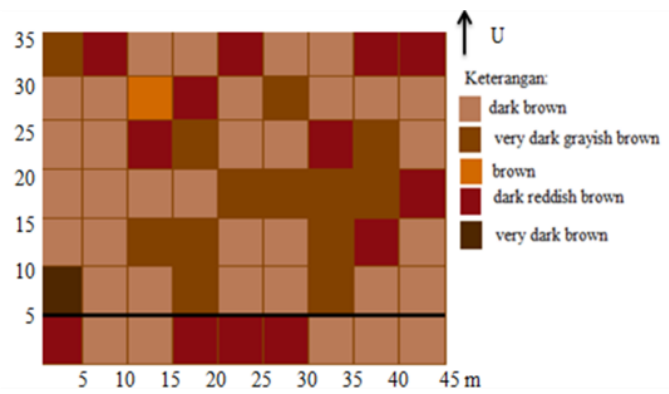

Gambar 2 Pemetaan warna tanah di tegakan pinus HPD

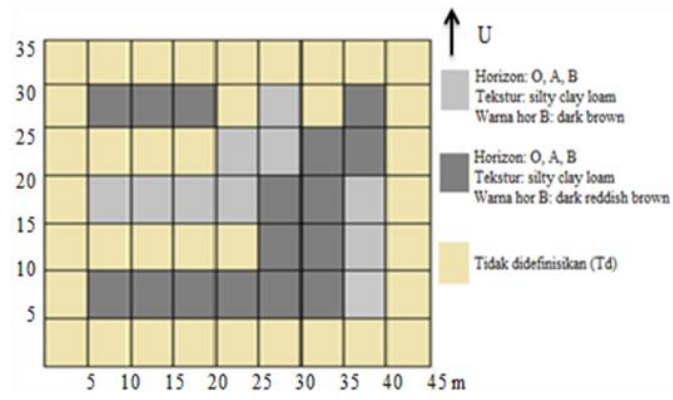

Gambar 3 Pemetaan tipe horizon tanah di tegakan pinus HPD

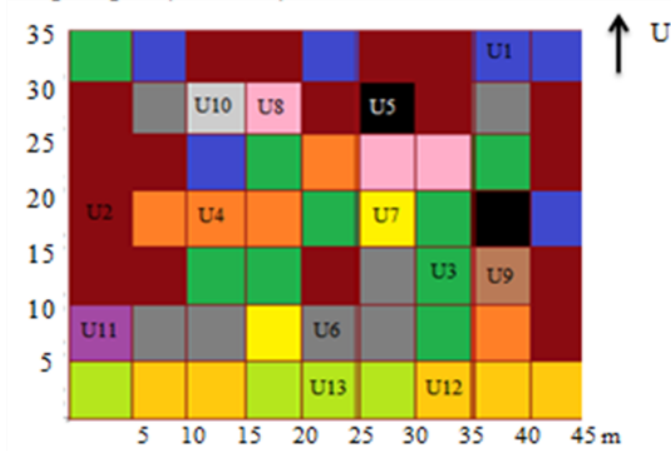

Gambar 4 Pemetaan 13 unit contoh tanah di tegakan pinus HPD
Kelompok unit contoh yang memiliki sifat kimia (Corganik, pH, kejenuhan alumunium, KTK) dan sifat fisik tanah (bulk density dan porositas) sama kemudian dikelompokan. Didapat 6 unit lahan dari beberapa kelompok unit contoh yang memiliki sifat tanah sama.

Unit lahan disajikan dalam bentuk peta. Unit lahan yang berbeda ditandai dengan warna yang berbeda pada peta.

\section{Warna tanah}

Warna tanah pada tegakan pinus petak 163 secara umum adalah brown (coklat), dengan kadar kegelapan yang berbeda-beda. Perbedaan warna permukaan tanah umumnya dipengaruhi oleh kandungan bahan organik (Hardjowigeno 2007).

Tingkat kandungan bahan organik bergantung pada tebal serasah yang ada, karena serasah merupakan salah satu bahan yang didekomposisi fauna tanah menjadi bahan organik. Rata-rata ketebalan serasah terendah terdapat pada kelompok 4 yang warna tanahnya brown saja, yaitu $3 \mathrm{~cm}$. Rata-rata ketebalan serasah lebih tinggi terdapat pada warna tanah yang lebih gelap dengan sedikit tambahan warna kemerahan yaitu pada kelompok 2 dengan warna dark reddish brown dan rata-rata ketebalan serasah $3.62 \mathrm{~cm}$. Rata-rata ketebalan serasah semakin lebih tinggi yaitu $3.81 \mathrm{~cm}$ pada warna tanah yang lebih gelap lagi dengan tambahan warna keabuabuan (very dark grayish brown). Sementara pada kelompok 1 yang memiliki warna tanah coklap gelap (dark brown) memiliki rata-rata ketebalan serasah tertinggi yaitu $4.48 \mathrm{~cm}$. Hal ini menunjukkan adanya kecenderungan perubahan warna tanah dari coklat saja (brown) menuju coklat gelap yang murni (dark brown) seiring dengan meningkatnya ketebalan serasah. Namun

Tabel 1 Rata-rata tebal serasah pada 5 kelompok warna tanah

\begin{tabular}{ccc}
\hline kel & Warna & $\begin{array}{c}\text { Rerata tebal } \\
\text { serasah } \\
(\mathrm{cm})\end{array}$ \\
\hline 1 & Dark Brown & 4.48 \\
2 & Dark Reddish Brown & 3.62 \\
3 & Very Dark Grayish & 3.81 \\
& Brown & 3.00 \\
4 & Brown & 3.00 \\
5 & Very Dark Brown & \\
\hline
\end{tabular}

Tabel 2 Kelompok unit contoh hasil overlay warna dan horizon tanah

\begin{tabular}{|c|c|c|c|c|}
\hline $\begin{array}{l}\text { Kel. } \\
\text { unit } \\
\text { contoh }\end{array}$ & Warna tanah & $\begin{array}{c}\text { Tipe } \\
\text { horizon }\end{array}$ & $\begin{array}{l}\text { Luas } \\
\left(\mathrm{m}^{2}\right)\end{array}$ & Titik amatan \\
\hline $\mathrm{UC} 1$ & Dark Reddish Brown & $\mathrm{Td}$ & 150 & $2,8,8 b, 5,19,25 \mathrm{~b}$ \\
\hline UC 2 & Dark Brown & Td & 425 & $\begin{array}{r}3,4,6,7,9 \mathrm{~b}, 24 \mathrm{~b}, 16,17,18,32 \\
33,34,37,40 \mathrm{~b}, 41 \mathrm{~b}, 10,12\end{array}$ \\
\hline UC 3 & $\begin{array}{l}\text { Very Dark Grayish } \\
\text { Brown }\end{array}$ & $\mathrm{Td}$ & 225 & $1,20,28,42,39,26,35,36,24$ \\
\hline UC 4 & Dark Brown & Tipe 1 & 125 & $21,29,30,31,41$ \\
\hline UC 5 & $\begin{array}{l}\text { Very Dark Grayish } \\
\text { Brown }\end{array}$ & Tipe 1 & 50 & 25,11 \\
\hline UC 6 & Dark Brown & Tipe 2 & 175 & $15,9,38,43,44,47,46$ \\
\hline UC 7 & $\begin{array}{l}\text { Very Dark Grayish } \\
\text { Brown }\end{array}$ & Tipe 2 & 50 & 45,27 \\
\hline UC 8 & Dark Reddish Brown & Tipe 2 & 75 & $23,13,22$ \\
\hline UC 9 & Dark Reddish Brown & Tipe 1 & 25 & 40 \\
\hline UC 10 & Brown & Tipe 2 & 25 & 14 \\
\hline UC 11 & Very Dark Brown & $\mathrm{Td}$ & 25 & 48 \\
\hline UC 12 & Dark Brown & $\mathrm{Td}$ & 125 & $50,51,55,56,56 \mathrm{~b}$ \\
\hline UC 13 & Dark Reddish Brown & $\mathrm{Td}$ & 100 & $49,52,53,54$ \\
\hline
\end{tabular}

Ket: Td: tidak didefinisikan 
terdapat perbedaan pada kelompok 5 yang rata-rata ketebalan serasahnya rendah namun memiliki warna tanah very dark brown.

Perbedaan warna pada kelompok 5 dapat disebabkan karena kombinasi jenis serasah. Area bagian depan dan sisi kanan tegakan pinus terdapat tegakan Shorea sp dan carapa (Carapa guianensis Aubl.). Jatuhan serasah dari berbagai sumber dan terdekomposisi pada area kelompok 5 diduga mempengaruhi warna tanah menjadi lebih gelap.

\section{Horizon tanah}

Terdapat jumlah jenis horizon penyusun yang sama yaitu $\mathrm{O}, \mathrm{A}$, dan B pada semua tipe horizon yang diamati, dengan batas antar jenis horizonnya yang baur. Selain itu, tekstur dari seluruh tipe horizon yang diamati dan setiap jenis horizonnya juga sama yaitu silty clay loam atau lempung klei berdebu sehingga perbedaan tipe horizon dibedakan atas warnanya (dark brown untuk tipe 1 dan dark reddish brown untuk tipe 2, pada horizon B). Titik amatan yang tidak dikelompokkan tipe horizonnya, dideskripsikan sebagai kelompok titik amatan yang berbeda.

Berdasarkan pengamatan di lapang, drainase tanah di tegakan pinus petak 163 Hutan Penelitian Dramaga termasuk baik karena tidak ditemukan bercak pada penampang horizon tanah. Keadaan drainase tanah di lapang dapat ditentukan dengan melihat gejala-gejala seperti adanya bercak karatan di dalam penampang tanah (Hardjowigeno 2007). Drainase tanah yang baik ini akan mempengaruhi pertukaran udara yang berjalan dengan lancar dan mendukung aktivitas perakaran dan organisme tanah.

\section{Kandungan C-organik pada setiap unit lahan}

C-organik adalah penyusun utama bahan organik. Bahan organik antara lain terdiri atas sisa tanaman dan hewan dari berbagai tingkat dekomposisi (Hayuningtyas 2006). Umumnya kandungan C-organik tanah pada tegakan pinus HPD petak 163, tergolong rendah. Namun pada unit lahan IV, V, dan VI yang letaknya berada tidak jauh dari sisi kanan tegakan memiliki kandungan Corganik yang sedang.

Nilai C-organik yang lebih tinggi pada unit lahan IV, $\mathrm{V}$, dan VI diduga dapat terjadi karena pada bagian sisi kanan tegakan terdapat tumpukan sampah organik berupa sampah bekas makanan, ranting-ranting, cabang, dan sampah anorganik. Menurut Rao (1975) dalam Setyorini et al (2015), Sampah organik dapat terdiri atas

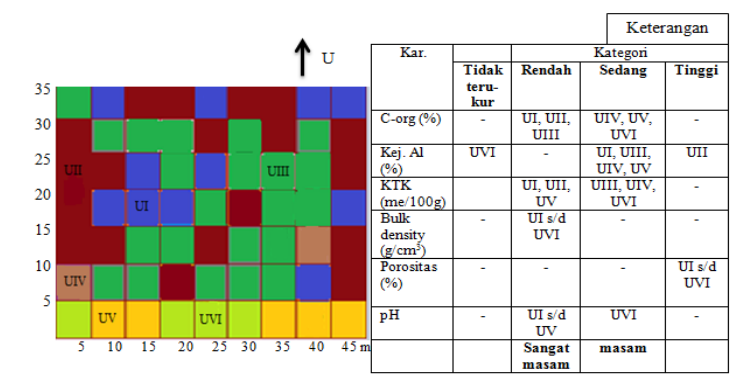

Gambar 5 Pemetaan 6 unit lahan di tegakan pinus HPD bagian tanaman ataupun sisa makanan yang mengandung karbon (C) dalam bentuk senyawa sederhana maupun kompleks. Ternyata sisa makanan dan tanaman yang tertumpuk pada bagian pinggir tegakan pinus berubah menjadi kompos secara alami. Kompos bisa terbentuk dengan sendirinya dengan interaksi antara cuaca, mikroorganisme, dan sampah itu sendiri pada lingkungan alam terbuka. Tumpukan sampah pada bagian pinggir tegakan pinus ternyata berkontribusi terhadap kandungan C-organik yang lebih tinggi dibanding pada area yang tidak terdapat tumpukan sampah atau hanya terdapat serasah pinus saja.

Selain sampah, Serasah Carapa guianensis banyak jatuh pada bagian sisi kanan tegakan (area unit lahan IV, V dan VI), dan serasah Shorea sp juga jatuh pada area unit lahan IV pada tegakan pinus. Hal itulah yang menyebabkan nilai C-organik pada unit lahan IV, V, dan VI lebih tinggi dibanding pada unit lahan lainnya. Kombinasi faktor keberadaan sampah dan berbagai jenis serasah yang terdekomposisi berkontribusi terhadap kandungan C-organik di dalam tanah pada area kelompok unit lahan tersebut.

Meskipun terdapat banyak serasah pinus di bagian dalam tegakan, namun tidak berkorelasi pada kandungan C-organik yang tinggi. Berdasarkan penelitian Hilwan (1993), serasah pinus terutama daunnya mengandung senyawa organik kelompok monoterpen berupa $\alpha$ pinene dan $\beta$-pinene yang sulit dirombak oleh mikroorganisme tanah dan berdampak pada laju dekomposisi serasah yang lambat $(4.53 \%$ per 2 minggu). Hal ini lah yang diduga menyebabkan kandungan Corganik yang rendah pada tanah yang tertutupi serasah pinus saja seperti pada area unit lahan I, II, dan III, karena serasah pinus belum terdekomposisi sempurna menjadi C-organik yang tersedia di dalam tanah.

\section{Derajat kemasaman (pH) dan kejenuhan alumunium (Al) pada setiap unit lahan}

Alumunium (Al) merupakan salah satu unsur hara dalam tanah yang menunjukkan tingkat kemasaman suatu tanah. Tersedianya unsur hara sangat dipengaruhi oleh $\mathrm{pH}$. Umumnya $\mathrm{pH}$ tanah pada tegakan pinus HPD adalah sangat masam hingga masam dengan kejenuhan Al dari sedang sampai tinggi. Jenis tanah latosol memang memiliki kandungan $\mathrm{pH}$ yang rendah dan $\mathrm{Al}$ yang tinggi (Buckman dan Brady 1961; Patrick 1971) dalam (Azizi 1995). Tanah-tanah yang kaya akan oksida Al merupakan

Tabel 3 Karakterisik kimia, fisik tanah, dan vegetasi pada unit lahan

\begin{tabular}{|c|c|c|c|c|c|c|c|c|c|}
\hline \multirow{3}{*}{$\begin{array}{l}\text { Unit } \\
\text { lahan }\end{array}$} & \multirow{3}{*}{$\begin{array}{l}\text { Unit } \\
\text { contoh }\end{array}$} & \multirow{2}{*}{\multicolumn{3}{|c|}{ Kimia tanah }} & \multicolumn{3}{|c|}{ Karaktensistik } & \multirow{2}{*}{\multicolumn{2}{|c|}{ Vegetasi }} \\
\hline & & & & & & Fisil & tanah & & \\
\hline & & $\begin{array}{l}\text { C-org } \\
(\%)\end{array}$ & $\mathrm{pH}$ & $\begin{array}{c}\text { Kejenuhan } \\
\text { Al } \\
(\%)\end{array}$ & $\begin{array}{l}\text { KTK } \\
(\mathrm{me} \\
100 \mathrm{~g})\end{array}$ & $\begin{array}{c}\text { Bulk } \\
\text { density } \\
\left(\mathrm{g}^{2} \mathrm{~m}^{3}\right)\end{array}$ & $\begin{array}{l}\text { Porositas } \\
(\%)\end{array}$ & $\begin{array}{l}\text { Rerata } \\
\text { tinggi } \\
(\mathrm{m})\end{array}$ & $\begin{array}{l}\text { Rerata } \\
\text { diameter } \\
(\mathrm{cm})\end{array}$ \\
\hline \multirow[t]{2}{*}{ I } & 1 & $\bar{R}$ & SM & $\mathrm{s}$ & $\mathrm{R}$ & $\frac{15}{R}$ & $\mathrm{~T}$ & & \\
\hline & 4 & R & SM & s & R & $\mathbb{R}$ & I & 26.25 & 42.75 \\
\hline \multirow[t]{2}{*}{ II } & 2 & $\ddot{R}$ & SM & I & $\ddot{R}$ & $\ddot{R}$ & I & 23.10 & 47.05 \\
\hline & 7 & $\mathrm{R}$ & SM & I & $\mathbb{R}$ & $\mathbb{R}$ & I & & \\
\hline \multirow[t]{5}{*}{ III } & 3 & $\mathrm{R}$ & SM & s & s & $\mathrm{R}$ & T & 24.72 & 43.34 \\
\hline & 6 & $\mathrm{R}$ & SM & s & s & $\mathrm{R}$ & T & & \\
\hline & 8 & $\mathbb{R}$ & SM & $\mathrm{s}$ & s & $\mathbb{R}$ & I & & \\
\hline & 10 & $\mathbb{R}$ & SM & s & s & $\hat{R}$ & T & & \\
\hline & & R & SM & s & $\mathrm{s}$ & $\mathrm{R}$ & I & & \\
\hline \multirow[t]{2}{*}{ IV } & 9 & S & SM & s & s & $\mathbb{R}$ & I & 25.50 & 49.68 \\
\hline & 11 & s & SM & s & \$ & $\mathrm{R}$ & I & & \\
\hline $\mathrm{V}$ & 12 & s & $S M$ & s & R & $\mathbb{R}$ & $I$ & 20.96 & 37.18 \\
\hline \begin{tabular}{|l}
$\mathrm{VI}$ \\
\end{tabular} & 13 & $\mathrm{~s}$ & M & & $\mathrm{s}$ & $R$ & $\mathrm{I}$ & 23.70 & 30.57 \\
\hline
\end{tabular}

Ket: SM (sangat masam), M (masam), R (rendah), S (sedang), T (tinggi), - (tidak terukur) 
tanah yang telah mengalami pelapukan lanjut (tua). Sebagai akibat dari pelapukan primer atau sekunder maka beberapa macam ion dibebaskan. Ion-ion yang sulit terlarut seperti alumunium akan mengalami rekristalisasi membentuk mineral-mineral baru atau senyawa-senyawa yang sukar larut (Hardjowigeno 2003). Kesukaran alumunium untuk larut lah yang menyebabkan banyak alumunium tertinggal di dalam tanah dan menyebabkan $\mathrm{pH}$ tanah menjadi masam.

Terdapat perbedaan dimana kandungan $\mathrm{Al}$ berada dalam jumlah sangat sedikit sehingga tidak terukur dalam analisis tanah pada unit lahan VI. Hal ini diduga masih dipengaruhi oleh keberadaan tumpukan sampah yang menjadi kompos alami bagi tanah. Unit lahan $\mathrm{V}$ yang juga berada di sisi kanan tegakan pinus, memiliki kejenuhan $\mathrm{Al}$ yang terendah bila dibandingkan lima unit lahan yang lainnya. Berdasarkan penelitian Wahjudin (2006), kompos sisa tanaman kedelai pada dosis $2 \%$ mampu mengikat Al sebanyak $9.63 \mathrm{cmol}(+) / \mathrm{kg}$. Kompos yang terdekomposisi menjadi bahan organik akan menghasilkan banyak asam organik seperti asam fenolat dan asam karboksilat. Asam-asam tersebut melalui gugus fungsionalnya akan menjerap Al sehingga aktivitas ion Al yang bersifat racun bagi tanaman menjadi berkurang (Tan 1982; Stevenson 1982; Gerke 1993 dalam Wahjudin 2006).

\section{Kapasitas Tukar Kation (KTK) pada setiap unit lahan}

KTK merupakan proporsi banyaknya kation (dalam miliekivalen) yang dapat dijerap oleh tanah persatuan berat tanah (Hardjowigeno 2007). KTK pada tegakan pinus HPD termasuk kategori rendah sampai sedang. Meskipun KTK pada area unit lahan III, IV, dan VI termasuk kategori sedang, namun besarnya nilai KTK tidak teralu signifikan yaitu berkisar 16.01 sampai 16.77 me/100g. Batas nilai KTK dikategorikan rendah yaitu di bawah 16 me/100g. KTK yang tidak tinggi ini diduga masih berhubungan dengan $\mathrm{pH}$ tanah yang masam. Derajat kemasaman yang tinggi menyebabkan lebih banyak ion $\mathrm{H}^{+}$di dalam tanah sehingga tanah berkurang kemampuannya dalam menjerap unsur hara lain yang bermuatan positif.

Tanah jenis latosol telah mengalami hancuran cukup intensif sehingga kapasitas tukar kationnya menjadi rendah. Hanya sedikit kapasitas kation tersisa untuk dipertukarkan dengan hara tanah. KTK yang rendah dapat menyebabkan proses penjerapan unsur hara oleh koloid tanah tidak berlangsung intensif, akibatnya unsurunsur hara tersebut akan dengan mudah tercuci dan hilang bersama gerakan air di tanah, dan pada gilirannya hara tidak tersedia bagi pertumbuhan tanaman (Ditjen Pendidikan Tinggi 1991).

\section{Bobot isi (bulk density) dan porositas tanah pada setiap unit lahan}

Bobot isi yang rendah sesuai literatur Supardi (1983) yaitu 0.73 sampai $0.93 \mathrm{~g} / \mathrm{cm}^{3}$ menunjukkan bahwa secara umum tanah di tegakan pinus petak 163 HPD tidak mengalami pemadatan. Tanah yang tidak padat pada tegakan pinus ini diduga karena tanah mengandung bahan organik yang didekomposisi dari serasah yang menutupi lantai hutan. Adanya bahan organik membuat tanah menjadi tetap gembur (Sutanto 2005).

Hardjowigeno (2007) menjelaskan, porositas tanah dapat dipengaruhi oleh kandungan bahan organik dan tekstur tanah. Nilai porositas tanah pada enam unit lahan di tegakan pinus HPD berkisar antara 64.76 sampai $72.50 \%$.

Tekstur tanah yang banyak mengandung fraksi pasir akan lebih poros dibanding fraksi lainnya. Tekstur tanah pada tegakan pinus HPD adalah lempung klei berdebu. Hal ini lah yang memungkinkan nilai porositas tanah tidak lebih dari $75 \%$, meskipun begitu kisaran nilai porositas tanah di tegakan pinus ini masih tergolong cukup baik (Supardi 1983). Tekstur tanah yang terlalu banyak mengandung pasir memang akan lebih poros dan lebih mudah meloloskan air, namun air tersebut sulit tertahan karena tekstur pasir memiliki banyak ruang kosong dan tidak memiliki muatan (untuk menahan air) seperti fraksi klei (Dariah et al 2009). Meskipun begitu, tekstur tanah yang didominasi klei juga tidak terlalu baik karena klei menahan air cukup kuat sehingga kecepatan tanah dalam meloloskan air ke bagian yang lebih dalam akan menjadi lebih lambat. Lempung merupakan proporsi seimbang antara klei, debu, dan pasir sehingga tekstur yang didominasi lempung seperti pada tegakan pinus HPD ini dinilai cukup baik dalam meloloskan dan menahan air untuk kemudian diserap tanaman.

\section{Sifat tanah pada setiap unit lahan dan pengaruhnya terhadap vegetasi}

Kombinasi sifat tanah yang berbeda menyebabkan pembagian unit lahannya menjadi berbeda pula. Penelitian ini menunjukkan bahwa dalam satu hamparan tegakan hutan yang tidak terlalu luas saja sifat fisik dan kimia tanahnya bisa berbeda. Dimungkinkan pada skala lahan yang lebih luas lagi sifat tanahnya akan lebih bervariasi. Oleh karena itu perlakuan yang diberikan untuk memperbaiki sifat tanah dan meningkatkan produktivitas lahan serta tegakan juga akan berbeda, bergantung pada parameter tanah yang bermasalah.

Unit lahan II memiliki kandungan C-organik yang rendah, $\mathrm{pH}$ sangat masam, kejenuhan alumunium tinggi, KTK rendah, Bulk density rendah, dan porositas tanah tinggi. Faktor pembatas seperti C-organik, pH, KTK yang rendah, dan kejenuhan alumunium yang tinggi pada unit lahan II memungkinkan pertumbuhan pinus menjadi lebih lambat. Hal tersebut dapat terlihat dari rerata tinggi pohon-pohon pinus di unit lahan II yang relatif rendah $(23.10 \mathrm{~m})$.

Unit lahan II memiliki kandungan C-organik yang rendah, pH sangat masam, kejenuhan alumunium tinggi, KTK rendah, Bulk density rendah, dan porositas tanah tinggi. Faktor pembatas seperti C-organik, pH, KTK yang rendah, dan kejenuhan alumunium yang tinggi pada unit lahan II memungkinkan pertumbuhan pinus menjadi lebih lambat. Hal tersebut dapat terlihat dari rerata tinggi pohon-pohon pinus di unit lahan II yang relatif rendah $(23.10 \mathrm{~m})$.

Unit lahan I memiliki sifat tanah yang sama seperti unit lahan II, namun terdapat parameter yang lebih baik, yaitu kejenuhan alumunium pada unit lahan ini lebih 
rendah. Sifat yang lebih baik ini memungkinkan pertumbuhan tinggi pohon pinus yang lebih besar, yaitu $26.25 \mathrm{~m}$. Pengaruh sifat tanah terhadap parameter diameter pinus tidak linier. Penelitian Adame et al. (2014) menjelaskan bahwa untuk mengetahui pengaruh nyata sifat tanah terhadap diameter pohon maka diperlukan pengamatan yang lebih lama atau lebih dari satu tahun.

KTK tanah lebih tinggi pada unit lahan III bila dibandingkan dengan unit lahan I, namun rerata tinggi pohon pinus yang berada pada unit lahan ini malah lebih rendah yaitu $24.72 \mathrm{~m}$ saja. C-organik lebih tinggi yang dikombinasi dengan tingkat kejenuhan $\mathrm{Al}$ tanah yang rendah dan kemampuan menjerap kation yang baik ada pada unit lahan IV. Hal ini memungkinkan pertumbuhan diameter pohon pinus di unit lahan ini menjadi yang terbesar dibanding unit lahan lainnya yaitu $49.68 \mathrm{~cm}$ dan tinggi pohon yang relatif besar yaitu $25.50 \mathrm{~m}$.

Memang ada pengaruh sifat tanah terhadap pertumbuhan tinggi dan diameter $P$. merkusii, namun besarnya pengaruh tersebut tidak signifikan. $P$. merkusii merupakan salah satu jenis pohon yang mampu bertahan terhadap kondisi tanah yang marginal, sehingga pengaruh sifat tanah yang buruk kurang jelas terlihat pada pertumbuhan pohonnya. Terdapat faktor lingkungan lain yang dinilai lebih mempengaruhi pertumbuhan pohon pinus yaitu adanya naungan.

Unit lahan VI memiliki kombinasi terbaik dibanding lima unit lahan lainnya, yaitu $\mathrm{C}$-organik lebih tinggi, $\mathrm{pH}$ tanah lebih tinggi, tidak jenuh akan alumunium, KTK cukup baik, dan bulk density serta porositas tidak menunjukkan adanya pemadatan tanah. Namun hal ini tidak berimplikasi pada pertumbuhan tinggi dan diameter pohon pinus yang lebih baik pada area unit lahan VI. Hal tersebut juga terjadi pada unit lahan III. Rerata tinggi dan diameter pohon yang berada pada kedua unit lahan ini lebih kecil dibanding unit lahan lainnya.

Diduga ada faktor lain yang menyebabkan pertumbuhan yang rendah pada pohon $P$. merkusii, yaitu jarak antar pohon yang terlalu berdekatan pada unit lahan III sehingga tajuk antar pohon menjadi tumpang tindih dan keberadaan naungan pohon carapa di sisi kanan tegakan pinus (berbatasan dengan unit lahan V dan VI).

Jumlah individu pinus yang ada pada unit lahan III yaitu 31 individu $550 \mathrm{~m}^{2}$ atau terdapat 31 individu dalam luasan $23.5 \mathrm{~m}$ x $23.5 \mathrm{~m}$ saja. Luasan yang sedikit dengan jumlah individu pinus yang cukup banyak menyebabkan tajuk antar individu pinus saling tumpang tindih dan menghalangi satu sama lain untuk mendapat cahaya matahari yang cukup.

Pinus merupakan jenis pohon intoleran yang memerlukan cahaya matahari penuh untuk mendukung pertumbuhannya (Sallata 2013). Area yang terlalu rapat menyebabkan terjadinya persaingan antar tajuk pohon dalam mendapatkan cahaya matahari, sehingga cahaya sebagai salah satu komponen dalam fotosintesis lebih sedikit didapat oleh pohon-pohon pinus yang rapat atau terpengaruh naungan tajuk carapa. Hal tersebut menyebabkan pertumbuhan diameter dan tinggi pinus menjadi lebih lambat.

\section{SIMPULAN DAN SARAN}

\section{Simpulan}

Sifat fisik tanah di tegakan pinus petak 163, Hutan Penelitian Dramaga bervariasi. Warna tanahnya terdiri atas 5 kelompok. Terdapat kecenderungan perubahan warna tanah dari coklat saja (brown) menuju coklat gelap yang murni (dark brown) seiring dengan meningkatnya ketebalan serasah. Horizonnya terdiri atas 2 tipe horizon dengan tekstur keseluruhan horizon yaitu silty clay loam, batas antar horizon baur, dan drainasenya tergolong baik karena tidak ditemukan bercak tanah. Didapat 13 unit contoh berdasarkan hasil overlay antara kelompok warna dan horizon tanah yang sama.

Unit contoh yang memiliki sifat kimia dan sifat fisik yang sama dikelompokkan dan terbagi ke dalam 6 unit lahan. Terdapat kecenderungan sifat tanah yang lebih baik menyebabkan pertumbuhan vegetasi di atasnya menjadi lebih baik pula. Namun sifat tanah tersebut harus dibarengi dengan faktor lain seperti naungan pohon yang diatur sedemikian rupa sehingga keduanya mampu mendukung pertumbuhan pohon pinus secara optimal.

\section{Saran}

Diperlukan penambahan parameter sifat fisik dan kimia tanah yang lain untuk mengetahui keseluruhan kondisi tanah di bawah tegakan pinus. Diperlukan pula pengamatan yang lebih intensif untuk mengetahui pengaruh naungan dan jarak antar pohon terhadap riap pohon pinus

\section{DAFTAR PUSTAKA}

Azizi MA. 1995. Beberapa sifat fisik dan kimia tanah latosol (Oxic Dystropept) Parung yang disawahkan. [Skripsi]. Bogor(ID): Jurusan Tanah, Fakultas Pertanian IPB.

Dariah A, Subagyo H, Tafakresnanto C, Marwanto S. 2009. Kepakaan Tanah terhadap Erosi. Bogor (ID): Balai Penelitian Tanah Litbang Pertanian.

Departemen Kehutanan. 1994. Kebun Percobaan Dramaga. Jakarta(ID): Badan Penelitian dan Pengembangan Kehutanan.

Direktorat Jenderal Pendidikan Tinggi. 1991. Kimia Tanah. Jakarta (ID): Depertemen Pendidikan dan Kebudayaan.

Hanafiah KA. 2005. Dasar-Dasar Ilmu Tanah. Jakarta (ID): PT Raja Grafindo Persada.

Hardjowigeno S. 2003. Klasifikasi Tanah dan Pedogenesis. Jakarta (ID) : Akademika Pressindo.

Hardjowigeno S. 2007. Ilmu Tanah. Jakarta(ID): Akademika Pressindo.

Hayuningtyas ADH. 2006. Perubahan sifat fisik dan kimia tanah dalam pelaksanaan sistem Tebang Pilih Tanam Jalur (TPTJ) di HPHTI PT. Sari Bumi Kusuma Unit S. Seruyan, Kalimantan Tengah. [Skripsi]. Bogor: Jurusan Budidaya Hutan, Fakultas Kehutanan, Institut Pertanian Bogor.

Hilwan I. 1993. Produksi, laju dekomposisi, dan pengaruh alelopati serasah Pinus merkusii Jungh. Et De Vriese dan Acacia mangium Willd. Di Hutan 
Gunung Walat, Sukabumi, Jawa Barat. [Tesis] Bogor (ID): Fakultas Kehutanan IPB.

Sallata MK. 2013. Pinus (Pinus merkusii Jungh et de Vriese) dan keberadaannya di Kabupaten Tana Toraja, Sulawesi Selatan. Info teknis EBONI. 2(10): 85-98.

Setyorini D, Saraswati R, Anwar EK. 2015. Kompos. Bogor (ID): Balai Penelitian Tanah.

Supardi G. 1983. Sifat dan Ciri Tanah. Bogor (ID): Institut Pertanian Bogor.
Sutanto R.2005. Dasar-Dasar Ilmu Tanah Konsep dan Kenyataan. Yogyakarta (ID): Kanisius.

Wahjudin UM. Pengaruh pemberian kapur dan kompos sisa tanaman terhadap alumunium dapat ditukar dan produksi tanaman kedelai pada tanah vertic hapudult dari Gajrug, Banten. Buletin Agronomi. 34(3): 141-147. 